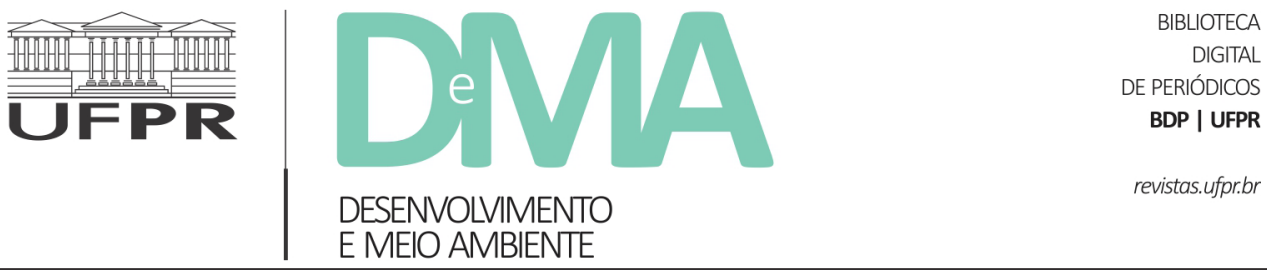

\title{
Parlamento, cidadão e políticas ambientais: a percepção dos participantes das audiências públicas na Câmara dos Deputados sobre meio ambiente
}

\section{Parliament, citizen and environmental policies: the perception of participants in public hearings in the Brazilian Chamber of Deputies on the environment}

\author{
Antonio Teixeira de BARROS ${ }^{1 *}$ \\ ${ }^{1}$ Programa de Pós-Graduação do Centro de Formação da Câmara dos Deputados (CEFOR), Brasília, DF, Brasil. \\ *E-mail de contato: antonibarros@gmail.com
}

Artigo recebido em 3 de fevereiro de 2020, versão final aceita em 24 de novembro de 2020, publicado em 2 de outubro de 2021.

RESUMO: $\quad$ O artigo analisa as percepções de cidadãos que participaram das audiências públicas promovidas pela Comissão de Meio Ambiente e Desenvolvimento Sustentável (CMADS) da Câmara dos Deputados durante o ano de 2019. Foram aplicados 552 questionários, o que corresponde a uma amostragem de 71,22\% do público. A hipótese que guia o estudo é a de que a participação nas audiências públicas é motivada por um conjunto de fatores interrelacionados, como o vínculo com entidades ambientais, a atuação profissional na área ambiental e a identificação com partidos de orientação ecológica. Os dados confirmam a referida hipótese e mostram que existe um público relativamente assíduo às audiências, em função desses fatores. As percepções apresentam críticas à atuação dos parlamentares e dos representantes de órgãos governamentais no debate e ao baixo desempenho do Congresso Nacional na área de políticas ambientais. Por outro lado, a participação de representantes de entidades ecológicas é avaliada pelos respondentes como positiva, pois contribui para qualificar a discussão.

Palavras-chave: políticas ambientais; poder legislativo; Câmara dos Deputados; audiências públicas; percepções ambientais.

ABSTRACT: The article analyzes the perceptions of citizens who participated in the public hearings promoted by the Environment and Sustainable Development Commission (CMADS) of the Chamber of Deputies during 2019. A total of 552 questionnaires were applied, which corresponds to a sampling of $71,22 \%$ of the audience. The hypothesis that guides the study is that participation in public hearings is motivated by a set of interrelated

Desenvolv. e Meio Ambiente usa uma Licença Creative Commons - Atribuição-NãoComercial-SemDerivações 4.0 Internacional 267 
factors, such as the link with environmental entities, professional performance in the environmental area, and identification with ecologically oriented parties. The data confirm this hypothesis and show that there is a relatively assiduous audience at the hearings because of these factors. The perceptions present criticisms to the performance of parliamentarians and representatives of government agencies in the debate and the low performance of the National Congress in the area of environmental policies. On the other hand, the participation of representatives of ecological entities is assessed by the respondents as positive, since it contributes to qualify the discussion.

Keywords: environmental policies; legislative power; chamber of deputies; public hearings; environmental perceptions.

\section{Introdução}

$\mathrm{O}$ artigo tem como objetivo analisar as percepções de cidadãos que participaram das audiências públicas promovidas pela Comissão de Meio Ambiente e Desenvolvimento Sustentável (CMADS) da Câmara dos Deputados durante o ano de 2019. $\mathrm{O}$ foco da análise compreende a percepção dos cidadãos no que se refere aos seguintes aspectos: (a) qualidade dos debates; (b) a participação dos atores institucionais, como os parlamentares, representantes de órgãos governamentais e de entidades ambientais; (c) temas mais relevantes para o debate ambiental na atualidade; (d) importância das leis ambientais aprovadas desde a década de 1980 .

A hipótese que guia o estudo é a de que a participação de cidadãos nas audiências públicas é motivada por um conjunto de fatores inter-relacionados, como o vínculo com entidades ambientais, a atuação profissional na área ambiental e a identificação com partidos de orientação ecológica.

A opção pelo exame das percepções se justifica pelo seu amplo uso nas ciências sociais, ancorado no princípio analítico denominado de dupla hermenêutica (Giddens, 2009, p. 335), ou seja, o analista das percepções sociais tem como objeto de investigação empírica fenômenos "já constituídos como significativos para os atores investigados", ainda que nem sempre discursivamente formulados. É importante ressaltar, portanto, que o produto final de análises dessa natureza resulta de um "duplo processo de tradução e interpretação que está envolvido nas operações e relações de pesquisa e na elucidação da capacidade cognitiva dos atores sociais", com o propósito de compreender suas opiniões e justificações discursivas (Barros, 2013, p. 341).

A literatura sobre o estudo de percepções sociais ressalta, em termos gerais, que se trata de um caminho metodológico para a compreensão do que os cidadãos pensam sobre determinados problemas sociais e políticos (Filgueiras, 2009; Quadros \& Frei, 2019). Convém ressaltar que o termo percepção social se refere a variadas formas de interpretação do mundo social pelos indivíduos, incluindo a política ambiental (Barros, 2019). As percepções ambientais são entendidas como a maneira pela qual cada indivíduo avalia questões e problemas relacionados ao ambiente, seja acerca do meio circundante ou sobre temas relativos à agenda ambiental de forma mais ampla, incluindo a ação dos atores sociais, políticos e governamentais (Fernández, 2008; Barros, 2019). Para os autores, o estudo de percepções ambientais pode contribuir para aperfeiçoar as políticas de gestão ambiental, aumentando sua legitimidade, ao adotar perspectivas que contemplem o interesse coletivo. 
Marin (2008), Carvalho \& Steil (2013), e Quadros \& Frei (2019) registram que a origem dos estudos sobre percepção está na psicologia, disciplina que incrementaria sua contribuição com a emergência da psicologia ambiental (Lee, 1977; Gibson, 1979), a partir de 1960. Os estudos sobre percepção passaram a contar ainda com as contribuições da geografia humanística (Tuan, 1972; Holzer, 1996), além dos aportes da fenomenologia, com as análises de Merleau-Ponty (1999) sobre fenomenologia da percepção.

Na psicologia percepção é entendida como a "organização das informações transmitidas pelas sensações que permitem conhecer a realidade". A percepção "dá-se em função das propriedades da estimulação sensorial que, por sua vez, derivam das propriedades do meio e dos seus objetos" (Mesquita \& Duarte, 1996, p. 50). A psicologia ambiental prioriza o estudo das percepções a partir da interação dos indivíduos com o meio ambiente, enquanto a geografia humanística enfatiza o papel dos valores culturais na conformação das percepções sobre a paisagem e o espaço. A fenomenologia, por sua vez, considera as relações entre corpo, percepção e conhecimento (Nóbrega, 2008).

Assim como as percepções sociais, as percepções ambientais são ancoradas em substratos culturais dos indivíduos, os quais são socialmente compartilhados em contextos específicos ou em relação a determinados temas (Canevari et al., 2019; Lobão, 2019). Esses suportes culturais compreendem as visões e representações das pessoas sobre a natureza e a relação do ser humano com os recursos naturais. Essa perspectiva pressupõe que a cultura constitui uma fonte de sentidos para os problemas sociais e ambientais (Ingold, 2000; Milton, 2002; Lobão, 2019). Para Mary Douglas
(1978; 1988; 2013; Quadros \& Frei, 2019), as percepções individuais são construídas a partir de uma determinada ordem cultural, com os cultural bias, que conformam os sentidos sobre as questões postas aos cidadãos, cuja referência são os sistemas simbólicos, os quais são socialmente compartilhados, legitimados e redefinidos com o passar do tempo e conforme as mudanças e dinâmicas socioculturais de cada contexto (Barros, 2017b; Lobão, 2019).

Nessa visão, as percepções são provenientes tanto da experiência direta dos indivíduos quanto da interação social e da exposição aos conteúdos midiáticos, que se tornaram agentes culturais de grande expressividade. Nessa ordem de ideias, é cabível ressaltar que a própria noção de meio ambiente é social e culturalmente construída (Durand, 2008; Barros, 2019), bem como as demais noções associadas às questões ecológicas, incluindo o indivíduo e suas representações pessoais (Allouche \& Nicolas, 2015; Canevari et al., 2019), contemplando também a dimensão cognitiva, ou seja, o modo como os indivíduos apreendem os problemas e questões relacionadas ao ambiente (Quadros \& Frei, 2019).

As percepções ambientais são complexas, a depender do tema e do público. Há questões relativamente consensuais, como o aquecimento global e a poluição, mas também existem temas em que as percepções são muito variadas ou até mesmo equivocadas, a depender do nível de conhecimento técnico necessário para a compreensão do problema em debate (Dunlap, 1998; Barros, 2017a). Para Yearley (2014) e Barros (2019), as percepções ambientais, em termos globais, foram amplamente influenciadas pela "onda verde" que se constituiu a partir da década de 1990. Essa onda, cujo marco foi a Rio 92, contribuiu para disseminar a consciência ambiental, sob uma perspectiva de que defender a 
agenda ecológica é uma atitude progressista e elegante, levando tal agenda a ser adotada, inclusive, por políticos, empresários e agências de publicidade (Barros, 2019).

Para captar as percepções dos cidadãos foram aplicados 552 questionários, o que corresponde a uma amostragem de $71,22 \%$ do público que acompanhou as 31 audiências públicas da CMADS durante todo o ano de 2019 (Apêndice 1). O detalhamento da metodologia será feito na abertura da análise dos dados. Antes, o texto apresenta um breve panorama sobre a emergência da teoria política verde, a atuação dos parlamentos na área ambiental e as audiências públicas.

\section{Emergência da teoria política verde e atuação dos parlamentos na área ambiental}

Desde o início da década de 1970, os países ocidentais de maior expressão econômica e política passaram a produzir estudos, relatórios, programas e planos de desenvolvimento que passaram a considerar a questão ambiental, a qualidade de vida e o desenvolvimento durável. Essa agenda passou a integrar um novo domínio da governança política e econômica, não só em nível nacional, mas global e local, com o apoio de instituições e entidades como o Clube de Roma, a ONU, a Organização para a Cooperação e Desenvolvimento Económico ou Econômico $(O C D E)$, o Conselho da Europa, entre outros (Lobão, 2019).

O Conselho da Europa decretou o ano 1970 como o "Ano Europeu para a Conservação da Natureza", um marco para as políticas ambientais nos países europeus, fortalecido pela realização da I Conferência das Nações Unidades sobre Ambiente e Desenvolvimento, realizada em Estocolmo, em 1972. Nos anos seguintes, o meio ambiente passou a ser considerado tema estratégico na gestão racional da economia. A interação entre estados nacionais, governança ecológica global e os movimentos sociais ambientalistas de caráter liberal contribuiu para a emergência dos "estados verdes", a exemplo da Noruega, Suécia, Dinamarca e Holanda (Jamison \& Cramer, 1991; Dryzek et al., 2003; Barros, 2017b).

A atuação das organizações ambientalistas de natureza global causou impactos expressivos nos marcos regulatórios ambientais em praticamente todos os continentes, em especial na América Latina (Barros, 2017a). A globalização dos riscos ambientais e seus impactos sobre os global commons impulsionaram outros países à adesão de políticas e de legislação mais favoráveis à perspectiva da sustentabilidade (Fiorino, 1989; Hardin, 2009; Barros, 2015a).

Embora haja uma longa e conhecida tradição teórica nas ciências humanas e sociais sobre o campo ambiental, a constituição de uma teoria política verde (com o protagonismo de autores da área da ciência política ou de cientistas sociais preocupados com questões políticas) é recente. A emergência de um campo teórico abrangendo política e meio ambiente ou teoria política verde é apontada na literatura como corolário da consolidação de uma agenda política ancorada em valores pós-materialistas nas democracias avançadas (Inglehart, 1981; Barros, 2015b).

$\mathrm{Na}$ visão do autor, os valores políticos são (re)definidos na confluência entre as necessidades individuais e as necessidades coletivas e são aceitos ou modificados no processo de socialização política. Os valores materialistas estão associados à satisfação de necessidades básicas, como alimentação, 
segurança, trabalho e saúde, por exemplo (Barros, 2019). Os valores pós-materialistas, por sua vez, passariam a ter lugar nas sociedades em que os indivíduos alcançam níveis de vida social e economicamente mais elevados, com maior qualidade material de vida. Assim, passariam a se preocupar com a satisfação de outra ordem de necessidades, a partir de valores como igualdade, liberdade, sustentabilidade ambiental, equidade nas relações sociais, liberdade religiosa, tolerância, respeito aos direitos humanos, incluindo o direito a um ambiente ecologicamente equilibrado (Barros, 2017b).

A teoria política verde ou green political theory emerge na esteira dessa cultura política pós-materialista. Os primeiros estudos surgem na década de 1980, com um avanço expressivo ao longo da década de 1990, período de consagração da agenda verde no plano internacional. Cabe uma breve abordagem sobre em que consiste a teoria política verde. Como emergiu? Como ela se caracteriza? O que propõe? Qual seu escopo analítico?

Antes de tudo, é oportuno esclarecer que não se trata de uma abordagem monolítica. Além disso, ainda "no existe una teoría política verde a la que podamos llamar canónica, um centro desde el que classificar desviacionses o variantes" (Maldonado \& Saiz, 1998, p. 80). Outro ponto consensual nas análises desses autores é que a chamada teoria política verde está em movimento contínuo. A teoria política do ecologismo apresenta muitas variações internas e subdivisões, porém converge para o investimento crítico no que se refere aos modelos consagrados de teoria política da democracia liberal, como representação, participação e deliberação. Os estudos filiados a essa vertente propõem uma renovação da democracia representativa, permitindo a ampliação da comunidade política, avançando nas modalidades de participação, a fim de consolidar uma cidadania ecológica (Doherty \& De Geus, 1996; 1999; Pellenz \& Arizio, 2019).

Para a teoria política verde, a participação cidadã no debate e nos processos decisórios sobre questões ambientais é fundamental para potencializar e fortalecer a dimensão participativa da democracia representativa. Isso se deve às heranças das origens dos movimentos ambientalistas que relacionavam a crise ecológica a uma crise de participação política (Eckersley, 1992; Barros, 2019). Influenciados por ideologias de esquerda, tais movimentos foram inspirados pelo debate sobre democracia radical e a defesa de uma guinada participativa na democracia (Pateman, 1970; Barber, 1984)1.

O problema da representação é tematizado na teoria política verde sob duas perspectivas. A primeira "como medio para hacer efectiva la extensión de la comunidade política dando cabida en ella a los extrangeros, las generaciones futuras y el mundo humano". A segunda se refere à "adecuada representación de los interesses medioambientales em el processo político de representación de interesés y adopción de decisiones" (Maldonado \& Saiz, 1998, p. 82).

É consenso entre os autores da política verde que a crise ecológica não tem sido tratada de forma adequada pelas democracias liberais, pois há uma tensão quase insolúvel entre os ideais da democracia liberal e os problemas ambientais contemporâneos (Pellenz \& Arizio, 2019; Barros, 2019). Essa tensão

\footnotetext{
${ }^{1}$ A exceção foi o chamado modelo ecoautoritário que defendia um Estado forte, capaz de implantar um sistema eficiente de governança ecológica, ao contrário do ecoanarquismo que previa a supressão completa do Estado e de qualquer forma centralizada de poder em favor da autogestão comunitária da sustentabilidade (Eckersley, 1992).
} 
consiste na natureza territorializada da política liberal e na desterritorialização dos riscos e problemas ambientais, o que requer uma profunda revisão estrutural nas lógicas contratualistas e instrumentais que regem e organizam o Estado liberal, em função dos imperativos da crise ecológica e sua natureza desterritorializada (Plumwood, 1995; Barros, 2017b). Como o Estado liberal constitui um sistema político doméstico que prioriza a defesa de seu território e os interesses nacionais, colocando a autonomia, a liberdade e a participação em segundo plano, isso desfavorece questões relevantes para o ambientalismo como a moralidade altruísta, as identidades coletivas e as agendas locais (Barros, 2019). A prioridade do Estado liberal é a economia de mercado, que ignora a racionalidade ecológica e estimula os modelos de dominação e exploração da natureza (Barros, 2019).

O problema-chave é, portanto, que a democracia liberal tem como motor a representação liberal de interesses, o que significa, na maioria dos casos, interesses econômicos, predominantemente contrários à agenda ecológica. A formação de preferências e de interesses é geralmente conduzida pelas elites políticas e econômicas que representam e expressam as demandas do capital (Sáiz, 2000; Barros et al., 2018). A teoria política verde, por outro lado, postula que os sistemas políticos necessitam de mais abertura para a incorporação efetiva das questões ambientais. Tal abertura implica a adoção de uma política de recuperação, visto que o ecologismo político é essencialmente recuperador e integrador de interesses e perspectivas, incluindo a perspectiva cidadã nas decisões políticas e na formulação das políticas ambientais (Guitián, 1995; Barros, 2019).

Apesar de recente, esse campo de estudos já pode ser classificado em várias fases. A primeira relacionava as convergências da agenda ambiental e da agenda política em termos gerais, presente em análises sobre política ecológica (Porrit, 1984), modernidade e ambientalismo (Pepper, 1984), o início do desenho de um cenário de uma possível globalização da agenda política verde (Spretnak \& Capra, 1985; Paehlke, 1989; Barros et al., 2018) e o debate sobre a escassez dos recursos naturais (Lee, 1989). Como se vê, a primeira fase não conseguiu sistematizar uma discussão consistente em termos de proposição de uma teoria política verde, porém, contribuiu para chamar a atenção da comunidade científica interessada em teoria política e meio ambiente. Embora nem todos os autores fossem cientistas políticos, a reflexão por eles protagonizada contribuiu para o início da constituição de uma comunidade epistêmica no âmbito das ciências sociais, com o foco em teoria política ${ }^{2}$.

A segunda fase consistiu na tentativa de formulação de uma teoria política verde de conotação radical, ancorada no marxismo (Sandler, 1994; Luke, 1997; Benton, 1998; Barros et al., 2018). É a fase das teorias políticas ecossocialistas ou ambientalismo radical, cujo cerne estava no questionamento dos limites do regime de crescimento econômico regido pela lógica do capitalismo, o que inclui a crítica às desigualdades entre capital e trabalho. A convergência entre ecologismo e socialismo é apontada por Sáiz (2000; 2014) e Barros et al. (2018) como

\footnotetext{
${ }^{2}$ Dos autores mencionados apenas Robert Paehlke (1989) é cientista político. Apesar disso, os demais são considerados relevantes devido à contribuição deles para o despertar de uma reflexão política sobre o tema.
} 
um legado do debate político promovido pelas esquerdas europeias, formando uma esquerda verde, ou seja, uma convergência discursiva em torno de práticas políticas definidas no espaço ideológico do ecossocialismo (Sáiz, 2005, p. 64).

Um desdobramento relevante desta fase foram as análises de como se deu a incorporação da agenda verde pelos partidos políticos europeus, a partir da iniciativa do Partido Socialista francês, com a emergência do chamado "voto verde" (Sainteny, 1994; Barros, 2015a). A atuação do PS estimulou outros partidos, de diferentes orientações ideológicas a apoiarem as bandeiras ecológicas (Rohrschneider \& Miles, 2015), especialmente com a posterior politização do debate sobre mudanças climáticas ${ }^{3}$ (Pepermans \& Maeseele 2016; Ryan 2017)4.

Os partidos verdes são vistos como "um produto de novas preocupações políticas, mas ainda mais de contextos políticos nacionais" (Jahn, 1997). Segundo o autor, embora os verdes não sejam considerados muito influentes em termos de efetividade legislativa, o impacto da atuação deles é expressivo na cultura política e na opinião pública. Portanto, os verdes se tornaram peritos em estratégias instrumentais para manter a questão ambiental na agenda política. Além disso, o aumento do voto verde tornou os partidos ecológicos alvos de interesse para alianças e coligações eleitorais (Barros, 2015b).

A terceira fase compreende a teorização ambiental no âmbito da democracia representativa, com a emergência do chamado ambientalismo liberal. $\mathrm{O}$ ambientalismo liberal tornou-se predomi- nante na complexa e heterogênea rede de vertentes ambientais, ao se contrapor ao discurso pessimista sobre riscos ambientais e ressaltar a retórica otimista da sustentabilidade ou economia verde (Barros et al., 2018). Trata-se de uma visão conciliadora entre economia de mercado e política ambiental, pautada no discurso da sustentabilidade e do desenvolvimento sustentável. Em tal perspectiva, o bem de todos, inclusive o bem relativo ao meio ambiente natural, deve ser promovido e garantido através da livre operação da economia de mercado e da teoria política liberal (Anderson; Leal, [1993] 1998; Farhir Neto, 2006; Rodrigues, 2006; Barros et al., 2018).

James K. Wong (2016) e Barros et al. (2018) questionam se a democracia liberal poderia garantir a sustentabilidade ambiental. Para o autor existe um relevante dilema na democracia contemporânea, denominado por ele de "dilema da democracia verde", que resulta da expectativa de que sejam tomadas decisões políticas favoráveis às causas ecológicas, perante as práticas políticas de manutenção da ordem econômica capitalista, cuja base é a exploração de recursos naturais. Portanto, nem sempre os princípios da sustentabilidade podem ser satisfeitos e postos em primeiro plano na agenda governamental. Segundo os autores, o dilema postula que não existe uma relação lógica ou incondicional entre decisões democráticas e sustentabilidade ambiental. Mais especificamente, o autor aponta três condições plausíveis para a tomada de decisão ambiental coletiva: pluralismo robusto, preservação do consenso democrático e resultados ecológicos

\footnotetext{
${ }^{3}$ A literatura recente destaca uma polarização partidária nos Estados Unidos. De um lado estão os Democratas, que defendem as políticas de combate ao aquecimento global e de outro os Republicanos, contrários a tais medidas (Dunlap et al., 2016).

${ }^{4}$ Nesse debate destacam-se atualmente dois focos: modelos de governança global das questões climáticas (Franchini et al., 2017) e o desenvolvimento de tecnologias adequadas à nova realidade ambiental (Leff 2015; Jacobbi \& Giatti, 2017).
} 
efetivos. Para construir uma democracia verde é necessário, portanto, a busca de soluções democráticas para garantir a sustentabilidade ambiental.

Atualmente é fácil encontrar estudos sob os mais variados enfoques que contribuem efetivamente para a constituição de uma teoria política verde. Entre eles estão autores que discutem questões relativas à crescente incorporação do ambientalismo nas teorias políticas (Dobson, 1993; 1996a; 1996b; Doberty, 1996; Barry, 1999; 2014; Barros et al., 2018). Outros autores tematizam a democratização política do ambientalismo (Eckersley, 1992; Plumwood, 1995; Maldonado \& Saiz, 1998). Uma tendência crescente é a discussão sobre a participação democrática nas políticas verdes (Hayward, 1995; Maldonado \& Saiz, 1998; Barros, 2017b).

A quarta fase dos estudos passou a se concentrar na atuação dos parlamentos na área ambiental, com a criação de comissões para tratar do assunto. $\mathrm{O}$ pioneiro foi o Parlamento Europeu (PE), reconhecido na literatura como o pioneiro e o mais atuante parlamento no que se refere à inclusão da agenda ambiental, o que implicou na criação de uma comissão específica para cuidar do assunto, além do estímulo aos demais parlamentos nacionais do continente a também criarem comissões de meio ambiente (Bomberg \& Burns, 2007; Barros, 2015a). A atuação simbólica e efetiva do PE foi intensificada em função de seu papel no debate político relativo às mudanças climáticas e ao aquecimento global (Burns \& Carter, 2010; Barros, 2017a).

\section{A política verde no contexto brasileiro}

A política ambiental brasileira é considerada uma iniciativa tardia e fortemente influenciada pelas pressões externas, especialmente no que se refere às críticas internacionais acerca da falta de medidas efetivas para a preservação das florestas tropicais no ecossistema amazônico (Barros, 2017a). Além disso, os movimentos ambientalistas que contribuíram para impulsionar essas políticas são vistos como alinhados aos ideais ecológicos que se projetaram em países europeus, a partir do debate sobre o uso de armas nucleares na II Guerra Mundial. A literatura considera que a consolidação dos movimentos ambientalistas no Brasil se deve à combinação de duas dinâmicas: "a interação dos grupos de ativistas com as estruturas de oportunidades políticas e a articulação deles entre si” (Alonso et al., 2007, p. 167).

Quanto às estruturas de oportunidades políticas, os autores destacam o processo de redemocratização, a Assembleia Nacional Constituinte de 1987-88 e o contexto político criado pela Rio 92. O primeiro "incentivou a organização de grupos de protestos na sociedade civil, encaminhando a conversão de simpatizantes ambientalistas em ativistas". A Constituinte "compeliu os ativistas a escolherem entre diferentes estratégias de mobilização disponíveis e os levou a convergirem para uma coalizão de associações, em vez de um partido, como forma prioritária de apresentar suas reivindicações na esfera pública". Já a Rio 92 "impingiu à coalizão de associações a negociação de um único frame, cujo significado pudesse ser compartilhado pelo movimento como um todo" (Alonso et al., 2007, p. 167).

Do ponto de vista da institucionalização dos movimentos ambientalistas e a consequente incorporação de suas pautas pelos partidos políticos no Brasil, um aspecto relevante registrado na literatura diz respeito à atuação dos diretórios estaduais e municipais do PV, a partir do contexto de redemo- 
cratização e da promulgação da Constituição de 1988 (Vieira, 2016; Barros, 2019). Se a criação do PV, em 1986, foi motivada por fatores externos, como vimos anteriormente, a institucionalização e ramificação do partido pelas demais unidades da federação foi um processo diferenciado, com maior articulação com os movimentos ambientalistas locais e regionais, especialmente na Região Sudeste (Santos, 2008; Barros, 2019). Entretanto, a atuação do PV não se limitou a essas regiões, como demonstra Vieira (2016), ao analisar a institucionalização dos movimentos ecológicos e sua aproximação com o PV na Região Nordeste (Barros, 2019) 5 .

Outro aspecto relevante identificado na literatura sobre a institucionalização dos movimentos ecológicos brasileiros, ainda durante o regime autoritário, diz respeito à interlocução direta desses movimentos com instituições do Estado, dispensando a medição partidária. Esse processo foi facilitado por algumas características específicas dos movimentos ecológicos:

O fato é que o movimento ambientalista permitia a articulação de consensos e alianças entre os atores, grupos de interesse e conflitos existentes dentro deste cenário de disputas (...) Dito de outro modo, o movimento ambientalista estabelecia uma dinâmica de ação pouco agressiva ao Estado autoritário e esse caráter pouco ofensivo permitiu ao movimento uma maior articulação com o Estado (...) Essas iniciativas, antes de significar um comprometimento efetivo do governo brasileiro com a luta para a proteção ambiental, serviram como uma tentativa de atenuar a imagem negativa que o governo deixou no cenário externo devido à sua atuação na Conferência de Estocolmo (Vieira, 2016, p. 120).
As interfaces e conexões com o Estado são consideradas uma relevante faceta da institucionalização dos movimentos ambientalistas no Brasil e em países vizinhos, gerando o que Gudynas (1992) denomina de "uma extraña pareja". Entretanto, o autor aponta mais dois aspectos igualmente relevantes: a institucionalização não estatal, com a participação de movimentos ligados a sindicatos, partidos e entidades não governamentais; e a opção pela não institucionalização, com a recusa de alguns movimentos a serem cooptados pelo Estado, partidos e outras instituições políticas (Scagliola, 2002; Barros, 2019).

A aproximação dos partidos com os movimentos ambientalistas, contudo, é considerado um fenômeno tardio no Brasil e na América Latina. Segundo a avaliação do autor, em termos ambientais, os partidos têm sido atores políticos secundários:

Los partidos latino-americanos han llegado tarde a la cuestión ambiental: su acción ha sido más reactiva que proactiva, superada tanto por arriba como por abajo por la realidad. Por arriba, a partir de la consolidación de una agenda global que busca contrarrestar los efectos de la degradación del medio ambiente; por abajo, por la emergencia cada vez más recurrente de conflictos ambientales locales. En ambos los casos, han prevalecido otros instrumentos de incidencia ciudadana como las redes globales o transnacionales de organizaciones no gubernamentales o las organizaciones vecinales inmersas en conflictos ambientales (Scagliola, 2002, p. 8).

Apesar de serem reconhecidos como atores secundários, o autor ressalta que houve uma par-

\footnotetext{
${ }^{5}$ O PV foi fundado em 1986, na cidade do Rio de Janeiro, resultado da reunião de ex-exilados políticos, como ecologistas, artistas, intelectuais e ativistas, do movimento antinuclear.
} 
ticipação significativa, não só dos chamados partidos verdes, como no caso do PV no Brasil, mas também da adesão de outros partidos de esquerda, em função de alianças eleitorais, a exemplo do PT e do PV. Mesmo não sendo um partido ecológico, o PT é apontado na literatura como um partido "con vínculos históricos importantes con el ecologismo" (Scagliola, 2002, p. 9). Além da criação do Núcleo de Ecologistas do Partido dos Trabalhadores, em 1995, o autor menciona a inclusão de um capítulo sobre meio ambiente no programa partidário do PT, em 2002. A adesão de vários partidos à agenda verde contribuiu para "el reconocimiento de la necesidad de pensar políticas ambientales integrales y transversales a las demás políticas públicas" (Scagliola, 2002, p. 16).

Dessa forma, a agenda verde tornou-se um tema partidário transversal, unindo direita, centro e esquerda, especialmente quanto às propostas vinculadas à dimensão econômica da sustentabilidade, visto que "la mayoría de las propuestas partidárias apuestan al crecimiento económico como eje articulador del modelo de desarrollo. Y esto cruza a los partidos de todo el espectro ideológico de izquierda a derecha" (Scagliola, 2002, p. 12).

O Congresso Nacional é considerado uma das instituições com envolvimento mais tardio na área ambiental (Accioly e Sánchez, 2012, p. 97; Horochovski et al., 2020). Na Câmara dos Deputados, até o ano de 2004 as questões ambientais eram tratadas como temas secundários pela então Comissão de Defesa do Consumidor, Meio Ambiente e Minorias (CDCMM). No ano de 2004 é que foi criada a Comissão de Meio Ambiente e Desenvolvimento Sustentável (CMADS), resultado do desmembramento CDCMM. Suas atribuições foram definidas como: responsável pelo exame dos temas relacionados com (a) a política e sistema nacional do meio ambiente; (b) direito ambiental; (c) legislação de defesa ecológica; (d) recursos naturais renováveis; (e) flora, fauna e solo; (f) edafologia e desertificação; (g) desenvolvimento sustentável (Brasil, 2017).

Além disso, o Congresso Nacional brasileiro é apontado como uma instituição dominada por ideias e projetos que se alinham ao antiecologismo (Accioly \& Sánchez, 2012, p. 97; Horochovski et al., 2020).

Para os autores, existe atualmente um expressivo "movimento antiecológico" no interior das duas casas legislativas, com atores bem definidos, estratégias de ação eficientes e uma agenda em plena expansão a favor do agronegócio. Levantamento realizado pelos autores mostra que os deputados que integraram a Comissão de Meio Ambiente nos últimos anos contam com financiamento de campanhas por grandes empresas "ligadas ao agronegócio e que respondem a processos ambientais e trabalhistas". O estudo constata ainda uma "desigualdade de forças entre o grupo 'antiecológico' e o grupo ambientalista", com predominância do primeiro (Accioly \& Sánchez, 2012, p. 97; Horochovski et al., 2020). O argumento dos autores é que tal movimento não é exclusivo do parlamento e encontra ressonância em parcelas expressivas da sociedade e não apenas no setor produtivo.

A CMADS conta com 18 deputados titulares e 18 suplentes. Todos os titulares são do sexo masculino e duas mulheres entre os suplentes. A representação partidária é proporcional ao tamanho das bancadas, sendo o PMDB, PT e PSDB os que contam com mais deputados. 


\section{Audiências públicas}

Oriunda do direito anglo-saxão, a audiência pública é um dos mecanismos para assegurar a participação da sociedade civil nos debates políticos e administrativos, além de "uma arena relevante para a representação de interesses" (Resende, 2017, p. 230). Como um instituto aberto à participação de agentes individuais e coletivos, visa ao fortalecimento da "legitimidade da ação administrativa, formalmente disciplinada em lei, pela qual se exerce o direito de expor tendências, preferências e opções que possam conduzir o Poder Público a uma decisão de maior aceitação consensual" (Moreira Neto, 1992, p. 129).

No caso do Poder Legislativo, trata-se de "uma ferramenta capaz de levar aos parlamentares novas informações, o que pode alterar o curso do processo decisório" (Zampieri, 2013). O caráter informacional das audiências é um dos aspectos mais ressaltados nos estudos legislativos (Santos, 2016; Barros et al., 2019; Côrtes, 2020). Entretanto, estudiosos da sociologia política consideram as audiências públicas "espaços sociais de luta político-cognitiva" (Silva \& Barbosa, 2015, p. 84). Isso significa entendê-las como "um espaço de forças opostas, o que implica afirmar que não se trata de inferir à qual posição assiste razão, mas sim que as posições atuantes expressam 'pontos de vista"'. Cada ponto de vista expressa a perspectiva social relativa ao lugar que cada agente ocupa na sociedade, ou seja, "ao lugar do qual determinado entendimento sobre o mundo social tenta irradiar-se e impor-se como visão legítima sobre este" (Silva \& Barbosa, 2015, p. 84).
Para efeitos de aplicação analítica neste trabalho consideramos útil a combinação das três perspectivas teóricas acima referidas, o que requer entender as audiências públicas sobre meio ambiente no âmbito da Câmara dos Deputados como um misto de representação de interesses e de dispositivo informacional para os parlamentares, sendo que, nessas duas abordagens, há aplicação da noção de espaço de lutas político-cognitivas (Barros et al., 2019).

No Brasil, é resultado das motivações democratizantes que inspiraram a Constituição de 1988 (Bernardes \& Barros, 2010; Lobão, 2019; Côrtes, 2020). O Regimento Interno da Assembleia Constituinte previa formas de apresentação de sugestões de entidades representativas da sociedade por meio de plebiscito, referendo e apresentação de emendas populares. Entretanto, essas formas, que fortaleceram o caráter democratizante da nova Carta, eram extremamente complexas de efetivar e, por isso, alcançaram pouco resultado (Guerra, 2010; Barros et al., 2018; Lobão, 2019). As audiências públicas, portanto, tornaram-se o instrumento mais recorrente para a participação popular na elaboração das políticas públicas, tanto na esfera do Poder Legislativo, como nos demais poderes (Côrtes, 2020).

É oportuno ressaltar que se trata de um mecanismo inserido no rol dos direitos de participação política. Assim, o instituto das audiências públicas baseia-se no pressuposto de que o cidadão não deve ser mero observador da cena pública ou agente passivo do processo político ou administrativo (Troiano, 2015). Trata-se, pois, de um expediente considerado indispensável para o fortalecimento das práticas de democracia e de cidadania no contexto atual. Diferentemente da sessão pública, na qual 
o público apenas assiste ao debate, na audiência pública os representantes da coletividade podem se manifestar de forma ativa, assegurando aos cidadãos o direito de colaborar e de ser ouvido (Côrtes, 2020). Dessa forma, esse instrumento permite o fortalecimento dos vínculos entre a sociedade e o Estado, além de possibilitar a renovação do diálogo entre os agentes públicos e a população. É também considerado "mecanismo idôneo de formação de consenso da opinião pública", além de "elemento de democratização do poder e modo de participação no poder público" (Dal Bosco, 2002, p. 155).

O Poder Legislativo tem nas audiências públicas espaços democráticos de debates entre parlamentares e a sociedade que subsidiam os parlamentares para o exercício de suas funções institucionais (Guerra, 2010; Barros et al., 2018). A realização dessas audiências decorre de comando constitucional (art. 58, parágrafo $2^{\circ}$, inciso II, da CF de 1988), cabendo às duas Casas do Congresso Nacional sua implementação. Segundo Celso Ribeiro Bastos (1995), "as audiências públicas com entidades da sociedade civil são realizadas quando questões de interesse social ou mesmo de segmentos específicos da sociedade forem suscitadas, tais audiências, portanto, configuram espaços voltados ao debate coletivo".

Zorzal \& Carlos (2017, p. 24), ao estudarem audiências públicas no legislativo, ressaltam os fatores endógenos e exógenos. Os primeiros se referem à dinâmica interna, incluindo fatores como o formato, o perfil dos parlamentares e dos participantes. A análise desses três fatores "proporciona uma percepção sobre a efetividade da participação no momento deliberativo, ou seja, a avaliação do potencial da participação no interior das audiências públicas em suas características constituintes (deli- beração, debate, mobilização, negociação, decisão ou fiscalização)". Os fatores exógenos abrangem aspectos como a relação entre o poder Executivo e o Legislativo, a atuação dos grupos de pressão e as demandas de representantes dos entes federados, quando lhes convém. Entre os fatores endógenos, Serafim (2008) argumenta que o formato e a dinâmica participativa são os mais relevantes, pois afetam o nível de participação e a profundidade dos debates.

Para Serafim (2008), Barros et al. (2018), e Côrtes (2020) as audiências públicas constituem espaços de diálogo democrático entre os atores que dela participam, porém, dialogar não implica necessariamente acatar a vontade e a visão dos interagentes, posto que os parlamentares não são obrigados a acatar todas as propostas, sugestões e ressalvas dos expositores e participantes da sociedade civil.

A Câmara dos Deputados incorporou às rotinas de trabalho o debate com entes da sociedade civil. Esses debates são previstos pelo Regimento Interno da Câmara dos Deputados (RICD, artigos 255-258). As principais características das audiências públicas defendidas pelo RICD são a transparência e o debate efetivo sobre matéria relevante e de interesse coletivo, com espaço para todas as correntes de opinião encontráveis na sociedade. Trata-se de uma concepção idealizada de comissão como um corpo político orgânico e funcionalmente cooperativo e integrado. A esse respeito, é oportuna a menção à noção de Bourdieu de comissão como "um conjunto de pessoas investidas de uma missão de interesse geral e conclamadas a transcender seus interesses particulares para produzir propostas universais" (Bourdieu, 2011, p. 123)

A primeira audiência pública realizada pela Câmara dos Deputados após a promulgação da Carta Constitucional de 1988 ocorreu em 03/11/1988, 
promovida pela Comissão Interpartidária do Salário-Mínimo, com a presença de representantes patronais e sindicais, conforme relata em discurso publicado pelo Diário do Congresso Nacional o então deputado Maurílio Ferreira Lima (Barros; Monteiro \& Nóbrega Neto, 2019).

A cada ano, as 26 comissões permanentes e as várias comissões especiais da Câmara realizam anualmente quase mil audiências públicas ${ }^{6}$. A maioria absoluta delas ocorre de terça a quinta-feira, período em que os parlamentares concentram sua atividade em Brasília. Num cálculo simples ${ }^{7}$, percebe-se que a média de eventos de terça a quinta é de quase 15 por dia. Em raras ocasiões os deputados realizam audiências nos estados, e o fazem geralmente para tratar de temas de interesse das comissões especiais. Por esse motivo, muitos eventos acabam acontecendo ao mesmo tempo, nos plenários das comissões (Barros et al., 2018; Côrtes, 2020). A tendência tem sido de crescimento do número de audiências realizadas a cada ano. Se em 2002 foram 193, em 2015 foram 931.

Apesar dos aspectos normativos que ressaltam o potencial das audiências públicas, há alguns estudos que apresentam críticas ao modo como os debates são organizados. O estudo de Zorzal \& Carlos (2017, p. 40) sobre o orçamento capixaba mostra que "o número de participantes é baixo e a dinâmica predominante na fase de participação é a apresentação sistemática de demandas, em vez da instituição de um diálogo ou de um processo de negociação entre os atores envolvidos”.

\section{Análise dos dados}

Em 2019 a CMDAS realizou 31 audiências públicas, com uma média de 25 participantes por evento, totalizando 775 pessoas (Brasil, 2019). Desse total, obtivemos 552 sujeitos que se dispuseram a responder ao questionário, o que corresponde a uma amostragem de $71,22 \%$. Cabe ressaltar que tivemos o cuidado de evitar que a mesma pessoa respondesse ao questionário mais de uma vez.

O perfil exposto na Tabela 1 revela, na realidade, o perfil do público das audiências promovidas pela CMADS, com predomínio de homens, na faixa etária de 31 a 50 anos, com curso superior, renda familiar nas duas escalas mais elevadas, vinculados a entidades ambientais, com vínculo partidário predominante na categoria simpatizante. Destaca-se ainda o fato de 78,80\% trabalhar na área ambiental, especialmente no setor público, residentes principalmente no DF.

Chama a atenção a maioria masculina, um dado quase sempre ressaltado quando se trata do perfil de cidadãos que participam da vida pública e das arenas de debates políticos. Estudo de Barros et al. (2018) mostra percentuais similares em relação à participação nas audiências interativas promovidas pela Câmara dos Deputados, com $67,30 \%$ de homens e $32,70 \%$ de mulheres. Trata-se de uma herança cultural e política, resultante de um processo diferenciado de socialização política das mulheres, que tende a restringir a atuação delas na esfera privada, ao mesmo tempo que produz impedi-

\footnotetext{
${ }^{6}$ Além das audiências, a Câmara realiza quase 500 eventos por ano, entre seminários, conferências, congressos e exposições, conforme Bernardes \& Barros (2010).

${ }^{7}$ Excluindo os períodos de recesso, nos meses de janeiro e julho, os 2000 eventos são distribuídos entre 46 semanas, com realização em três dias consecutivos (terça a quinta-feira), totalizando 14,8 eventos por dia, segundo Bernardes \& Barros (2010).
} 
mentos e obstáculos quando se trata da participação na esfera pública (Biroli, 2016). Convém anotar um contraponto registrado na literatura de que o ambientalismo conta com expressiva militância feminina (Boy, 2002). Embora militância seja um campo distinto do tema aqui investigado, ressalta-se a predominância de homens na participação em audiências públicas da CMADS.

TABELA 1 - Perfil dos informantes.

\begin{tabular}{lcc}
\hline SEXO & Quant. & \% \\
\hline Masculino & 336 & 60,87 \\
Feminino & 216 & 39,13 \\
\hline Subtotal & 552 & 100,00 \\
\hline FAIXA ETÁRIA & Quant. & $\mathbf{\%}$ \\
\hline Até 20 anos & 10 & 1,8 \\
21 a 30 anos & 90 & 16,3 \\
31 a 40 anos & 223 & 40,4 \\
41 a 50 anos & 149 & 27 \\
51 a 60 anos & 64 & 11,6 \\
Acima de 60 anos & 16 & 2,9 \\
\hline Subtotal & 552 & 100 \\
\hline ESCOLARIADE COMPLETA & Quant. & $\mathbf{\%}$ \\
\hline Ensino Fundamental & 2 & 0,36 \\
Ensino Médio & 92 & 16,67 \\
Curso Superior & 344 & 62,32 \\
Pós-Graduação & 114 & 20,65 \\
\hline Subtotal & 552 & 100,00 \\
\hline RENDA FAMILIAR & 952 & 100,00 \\
\hline Até 3 salários mínimos & &
\end{tabular}

\begin{tabular}{|c|c|c|}
\hline $\begin{array}{l}\text { VÍNCULO COM ENTIDADE AM- } \\
\text { BIENTAL }\end{array}$ & Quant. & $\%$ \\
\hline Sim & 283 & 51,3 \\
\hline Não & 269 & 48,7 \\
\hline Subtotal & 552 & 100 \\
\hline VÍNCULO PARTIDÁRIO & Quant. & $\%$ \\
\hline Simpatizante & 234 & 42,4 \\
\hline Não filiado & 183 & 33,2 \\
\hline Filiado & 135 & 24,4 \\
\hline Subtotal & 552 & 100 \\
\hline $\begin{array}{l}\text { TRABALHA NA ÁREA AMBIEN- } \\
\text { TAL }\end{array}$ & Quant. & $\%$ \\
\hline $\operatorname{Sim}$ & 435 & 78,80 \\
\hline Não & 117 & 21,20 \\
\hline Subtotal & 552 & 100,00 \\
\hline SETOR DE ATUAÇÃO & Quant. & $\%$ \\
\hline Setor Público & 350 & 63,41 \\
\hline Terceiro Setor & 183 & 33,15 \\
\hline Setor privado & 19 & 3,44 \\
\hline Subtotal & 552 & 100,00 \\
\hline ESTADO & Quant. & $\%$ \\
\hline $\mathrm{DF}$ & 423 & 76,63 \\
\hline GO & 60 & 10,87 \\
\hline $\mathrm{MG}$ & 33 & 5,98 \\
\hline MT & 14 & 2,54 \\
\hline MS & 12 & 2,17 \\
\hline TO & 5 & 0,91 \\
\hline PR & 2 & 0,36 \\
\hline ES & 1 & 0,18 \\
\hline SP & 1 & 0,18 \\
\hline RS & 1 & 0,18 \\
\hline Subtotal & 552 & 100,00 \\
\hline
\end{tabular}

FONTE: Elaboração própria. 
Apesar de a filiação partidária ser de 24,4\%, chama a atenção o elevado percentual de informantes que se declaram simpatizantes $(42,4 \%)$. Somadas essas duas categorias temos 66,8\%. A simpatia é considerada na literatura uma forma de identificação partidária, pois expressa claramente uma preferência política, embora não haja o vínculo formal da filiação. Na realidade, as duas categorias são formadas por simpatizantes, sendo que os filiados decidem formalizar sua simpatia partidária (Cabral, 1995).

A Tabela 2 mostra que há predominância de filiados aos partidos de orientação ecológica, sendo os primeiros o PV e a Rede, considerados adeptos da ecologia política sistêmica, ou seja, apresentam um perfil ecológico moderado, diferentemente dos partidos ambientalistas radicais ou ecossocialistas (Barros et al., 2018). Apesar das diferenças internas, PV e Rede convergem na defesa de uma visão integrada e sistêmica de sustentabilidade, reunindo várias dimensões como econômica, política, social, cultural, espacial e ambiental. Os debates promovidos pela CMADS parecem interessar bastante aos filiados dessas legendas, aliados a outros fatores, como atuação profissional e proximidade com entidades de defesa do ambiente.

A ecologia sistêmica integra e inter-relaciona todas essas dimensões, em consonância com a classificação de Ignacy Sachs (1993). Para o autor, a sustentabilidade econômica é focada na eficiência na alocação e gestão de recursos extraídos da natureza, além de racionalidade nos investimentos. A sustentabilidade social prioriza políticas de desenvolvimento humano, com o propósito de promover justiça social e reduzir desigualdades. A sustentabilidade espacial refere-se às políticas para a ocupação do solo e relação campo-cidade, por exemplo. A sustentabilidade cultural consiste no respeito às tradições, comunidades nativas e o patrimônio cultural. A sustentabilidade ecológica, por sua vez, tem como pilar a preservação das fontes de recursos energéticos e naturais, com base na premissa de que o uso econômico dos bens naturais deve considerar os ciclos temporais inerentes às especificidades de cada ecossistema, a fim de garantir o equilíbrio da biodiversidade.

Convém observar ainda que a filiação dos informantes se situa praticamente no espectro de esquerda e centro-esquerda, reunindo partidos que passaram a priorizar a sustentabilidade em seus programas no contexto recente, reunidos sob a alcunha de esquerda verde (Barros et al., 2018). Trata-se de um conjunto de legendas que, mesmo sem uma nítida orientação ecológica - diferentemente do PV e Rede -, aderiram à agenda ambiental de forma mais ostensiva, alinhados à crítica ao capitalismo e a retomada de ideias ecossocialistas, a exemplo do PDT, PSOL, PSB, PCdoB, PT e PCO. Embora haja diferenças nas ênfases atribuídas às questões ambientais em seus programas, tais agremiações compartilham o ideal da aproximação entre socialismo e sustentabilidade ecológica, cujo expoente foi o Partido Socialista francês (Sainteny, 1994; Duverger, 2011).

Os partidos mencionados conjugam em seus programas sustentabilidade econômica, social e ecológica, mas apenas no plano retórico,

pois não apresentam propostas específicas de governança ambiental. Em suma, os programas partidários ecossocialistas assemelham-se mais a manifestos anticapitalistas do que a programa de governança ambiental propriamente dito. Entretanto, o manifesto é coerente com a identidade e a trajetória dessas agremiações, cujo objetivo primordial é marcar posição no 
contexto da concorrência partidária e não propor governança efetivamente, visto que apresentam poucas chances de eleger candidatos para cargos executivos, como presidente da República ou governador (Barros et al., 2018, p. 20).

TABELA 2 - Partidos mencionados.

\begin{tabular}{lcc}
\hline \multicolumn{1}{c}{ Partidos } & Quant. & \% \\
\hline PV & 63 & 46,67 \\
REDE & 31 & 22,96 \\
PSOL & 12 & 8,89 \\
PSB & 11 & 8,15 \\
PDT & 5 & 3,70 \\
PT & 5 & 3,70 \\
PCdoB & 4 & 2,96 \\
PCO & 3 & 2,22 \\
PEN & 1 & 0,74 \\
\hline TOTAL & $\mathbf{1 3 5}$ & $\mathbf{1 0 0 , 0 0}$ \\
\hline
\end{tabular}

FONTE: Elaboração própria, 2019.

O público das audiências é relativamente assíduo, predominando as frequências mensal, bimensal e trimensal, conforme demonstrado na Tabela 3. Esses dados se explicam por outras variáveis expostas anteriormente na Tabela 1, como o trabalho na área ambiental e a vinculação com entidades ambientais e partidárias, conforme já foi ressaltado. A assiduidade é um fator positivo para a pesquisa aqui exposta, visto que qualifica a opinião dos entrevistados.
TABELA 3 - Você participa das audiências públicas sobre meio ambiente com que frequência?

\begin{tabular}{lcc}
\hline FREQUÊNCIA & QUANT. & \% \\
\hline Semanal & 0 & 0 \\
Quinzenal & 21 & 3,6 \\
Mensal & 137 & 24,8 \\
Bimensal & 114 & 20,7 \\
Trimensal & 128 & 23,3 \\
Semestral & 80 & 14,5 \\
Eventual & 45 & 8,2 \\
É a primeira vez que participo & 27 & 4,9 \\
\hline TOTAL & $\mathbf{5 5 2}$ & $\mathbf{1 0 0}$ \\
\hline
\end{tabular}

FONTE: Elaboração própria, 2019.

\section{Avaliação do público das audiências}

A Tabela 4 condensa todas as questões que expressam a avaliação do público ${ }^{8}$, relativamente positiva em todos os aspectos examinados. A ressalva diz respeito à atuação dos deputados nas audiências, com predomínio de avaliação regular. O desempenho dos convidados e expositores (coluna 3) e dos representantes das entidades ambientais são os quesitos com melhor avaliação do público.

As respostas abertas ${ }^{9}$ ajudam a aprofundar tais percepções. Quanto à avaliação das audiências, os argumentos positivos são os seguintes:

- Convidam técnicos de elevada qualidade para o debate.

\footnotetext{
${ }^{8}$ Cada coluna corresponde à apuração das respostas a uma questão específica, cujo elenco é o seguinte: Como você avalia (a) as audiências públicas promovidas pela CMADS; (b) a qualidade dos debates; (c) a atuação dos deputados nas audiências; (d) a atuação dos representantes governamentais; (e) a atuação dos representantes de entidades ambientalistas; (f) a atuação do Congresso Nacional nas políticas ambientais; (g) o desempenho do Brasil na proteção ambiental nos anos recentes.

${ }^{9}$ Para a análise das questões abertas recorremos à técnica de análise de conteúdo, mais especificamente a análise temática, entendida como agrupamento semântico das respostas, conforme o tema abordado pelos informantes (Bardin, 2011). As respostas das questões fechadas são apresentadas ao longo do texto na forma de estatísticas descritivas.
} 
- Trazem à tona assuntos relevantes.

- Qualidade dos debates e importância dos temas.

- Pouco público, mas bons expositores.

Os que criticam, apontam que:

- Há muitos atrasos, o que prejudica o tempo que deveria ser destinado ao debate.

- São pouco efetivas; nada de novo é feito.

- Pouca participação popular e baixa divulgação.

- Privilegiam o lado do governo; a voz dos ambientalistas fica em segundo plano, somente para constar.

Alguns aspectos chamam atenção na avaliação positiva do público, como a ênfase aos temas debatidos e a qualificação técnica dos convidados, o que nos leva a deduzir que as audiências da CMADS são reconhecidas por esse público como um fórum qualificado de debate ambiental. Como salientam Lima et al., (2017, p. 261), o Poder legislativo brasileiro passou por um processo de abertura nos últimos anos, "transformando-se em espaço político que sido cada vez mais ocupado por múltiplos interesses". Salta aos olhos a falta de menção à atuação dos deputados, cuja atuação não é bem vista pelos cidadãos consultados. Sob a perspectiva das críticas, contudo, alguns informantes consideram que as audiências "são pouco efetivas", pois "nada de novo é feito", em um enquadramento discursivo que condiciona a efetividade de um debate político a algum tipo de ação dele decorrente. Outros consideram as audiências da CMADS um espaço privilegiado para a legitimação retórica de representantes do Poder Executivo. A baixa participação social, deficiências na divulgação e os atrasos no início dos debates aparecem como aspectos negativos na avaliação do público.

Acerca da atuação parlamentar, os cidadãos apresentaram muitas críticas, tais como:

- Os poucos que comparecem não são efetivos defensores das causas ecológicas.

- Há pouca participação efetiva dos deputados.

- Vejo pouco interesse dos deputados.

- Deveriam ser mais presentes, já que as informações são dirigidas a eles.

- Demonstram pouca afinidade e conhecimento sobre os assuntos tratados.

- São muito desinformados.

TABELA 4 - Avaliação dos participantes das audiências públicas.



FONTE: Elaboração própria. 
'Convém registrar que não houve nenhuma manifestação positiva sobre a atuação dos deputados, os quais são percebidos pelos informantes como desinteressados, desinformados e sem comprometimento com as causas ecológicas. O juízo dos cidadãos deve ser considerado à luz da composição da CMADS no período em que o questionário foi aplicado. Dos 18 titulares da comissão, havia apenas um deputado da Rede Sustentabilidade. Todos os demais são vinculados a partidos sem histórico de alinhamento à agenda ambiental, com predomínio de parlamentares sem vínculos com movimentos sociais de orientação ecológica. Certamente é por essas razões que a avaliação do público se apresenta da forma como foi mencionada acima.

Quanto ao desempenho dos representantes governamentais, os informantes argumentam que:

- Normalmente apresentam suas realizações e se comprometem com ações nos seus setores de atuação.

- Elevado nível técnico.

- São especialistas de renome, com conhecimento e experiência sobre o que falam.

- Falta objetividade e capacidade de síntese.

- Os convidados dos setores governamentais são falaciosos e de pouco conhecimento técnico.

- Os que falam pelo Governo querem apenas convencer de que as medidas do estado são adequadas, sem abertura para um debate mais aprofundado e crítico.

Quanto aos convidados dos setores governamentais, as críticas se sobressaem, com destaque para as estratégias retóricas de justificação dos discursos e medidas oficiais. Apesar de as audiências da CMADS serem um espaço legítimo de expressão dos representantes oficiais, o uso estratégico desse espaço é questionado pelo público. Certamente tal perspectiva se deve ao predomínio de recursos retóricos por esses convidados para apresentar o discurso ambiental como algo consensual, institucionalizando um discurso uniformizado sobre as problemáticas ecológicas.

Segundo Carvalho (1990, p. 237), tal discurso regulamenta, estabelece metas e produz os fatos ecológicos, com base em justificações públicas meramente retóricas. Assim, "esse discurso nomeia como bom certo modelo de desenvolvimento e esta é a sua medida para a melhoria e o bem-estar. Clama pela preservação da natureza, comprometido de antemão com as regras do capitalismo industrial e do consumo" (ibid). Para a autora, em nome de conceitos portadores de uma generalidade estratégica, o Estado afirma e reafirma sua fala consensual institucionalizada, que estabelece efeitos de verdade e "produz ofato ecológico desde seu ponto de vista" (Carvalho, 1990, p. 235). Isso explica a natureza do discurso oficial, mais precisamente sua natureza persuasiva e simplificadora, que tenta impor à sociedade uma visão "domesticada" dos problemas ambientais (Barros, 2017b).

Ao se reportarem à atuação dos representantes de entidades ambientais, os cidadãos explicam que:

- Falam bem, conhecem a legislação e são especialistas sobre o que falam.

- São eles que formam opinião na área ambiental.

- Cumprem bem o seu papel, especialmente nos contrapontos dos debates.

- Trazem os pleitos da população local.

- O espaço de fala é muito curto, o que impede uma atuação melhor. 
Diferentemente, ao avaliarem a atuação dos representantes de entidades ambientais, os respondentes apresentam como única ressalva o curto tempo para a exposição desses atores. Dois aspectos devem ser aqui destacados. O primeiro é que a legitimidade das manifestações desses representantes perante a plateia parece estar respaldada no fato de que $51,3 \%$ dos respondentes do questionário são vinculados a entidades ecológicas. Logicamente que há $48,7 \%$ que são pertencem a nenhuma dessas entidades, os quais também não se manifestaram de forma crítica em relação aos expositores, levando-nos a crer que esse segundo segmento também avalia de forma positiva o desempenho discursivo desses atores.

O segundo aspecto está relacionado com a reconhecida competência discursiva das entidades ambientais, um fenômeno já registrado na literatura, fruto da necessidade dessas instituições de conquistarem espaço nos meios de comunicação e nas demais arenas de debate público. Pereira Rosa (2006) afirma que o êxito das organizações não governamentais do ambiente no campo da retórica ambiental contemporânea se justifica por uma mudança de posição e de paradigma: as entidades deixaram de ser apenas promotoras de protestos e manifestações para se tornarem referências em diagnósticos especializados, capazes de apresentar análises técnicas confiáveis sobre os temas em discussão pela agenda governamental e pela comunidade científica. Assim, ao deixarem de ser identificadas pelos jornalistas como portadoras de um capital simbólico baseado meramente no ativismo e no engajamento ambiental, essas organizações tornaram-se entidades especializadas, fontes peritas de alta credibilidade. Além disso, o autor analisa como essas entidades modelaram suas estratégias para formatar suas mensagens de modo a atrair a atenção dos media e os públicos interessados no tema.

Segundo Barros (2015b), isso resulta de um processo mais amplo que produziu mudanças no ethos ambientalista e na reformulação de seus repertórios de ação coletiva. Apesar da pluralidade, da diversidade de agenda e das vertentes discursivas dessas entidades (Nunes et al., 2017), a percepção dos informantes tende a ser uniforme quanto à avaliação da atuação dos representantes dessas entidades nas audiências da CMADS, o que nos leva a deduzir que todas as formas de discurso e ação delas são reputadas como válidas pelos cidadãos consultados.

Os debates são bem avaliados pelos participantes das audiências. Conforme exposto na Tabela 4, somando-se as avaliações excelente e boa, temos $82,80 \%$, corroborando a avaliação positiva das audiências em si. Entre as justificativas para tal resultado estão:

- Trazem dados e informações relevantes.

- Apresentam vários ângulos e facetas sobre os temas em debate.

- Apesar da fraca atuação dos deputados, os debates são de alto nível.

- A argumentação dos representantes de entidades ambientalistas qualifica o debate.

Como se vê, a qualidade dos debates é atribuída aos convidados externos, especialmente os representantes das entidades ambientais. A participação dos parlamentares mais uma vez é criticada. Entre as críticas apontadas estão:

- São superficiais.

- São muito polarizados.

- Falta a participação da plateia.

- São pouco democráticos. 
A percepção predominante é que o Brasil apresenta atuação regular em relação às políticas ambientais, no contexto recente. Entre os argumentos apresentados pelo público estão:

- $\mathrm{O}$ avanço da Bancada Ruralista tem cada vez mais força para boicotar as leis ambientais.

- Deixou de avançar em políticas públicas efetivas para a proteção da natureza.

- A agenda ambiental deixou de ser prioridade pelo Governo e pelo Legislativo.

- Parece haver um pacto tácito entre Governo e Congresso para impedir o avanço das políticas ambientais.

- Falta fiscalização ambiental rigorosa e efetiva, com punição de fato.

- Impunidade, a anistia de crimes ambientais e o perdão de multas milionárias estimula a devastação.

- O lobby do agronegócio está predominando no país.

- Os movimentos ambientais arrefeceram suas lutas.

Em relação ao avanço da chamada Bancada Ruralista, a percepção dos informantes encontra respaldo nos dados estatísticos compilados pelo Congresso em Foco em 2016 (Medeiros \& Fonseca, 2016). Conforme o levantamento, 207 deputados integram a Frente Parlamentar em Defesa da Agropecuária, o que corresponde a 40,35\% dos 513 deputados. Até mesmo a Frente Parlamentar Ambientalista conta com mais de $70 \%$ de seus integrantes alinhados aos interesses do agronegócio, confirmando a tendência já registrada na literatura de "antiecologismo" do Congresso Nacional (Accioly \& Sánchez, 2012).
A atuação do Congresso Nacional é o pior item da avaliação dos informantes, com 95\% de reprovação, somando-se as alternativas ruim e péssima. Tal desempenho é justificado discursivamente pelos seguintes argumentos:

- O Congresso Aprova leis ambientais novas sem revogar as antigas.

- Há o monopólio da Banca Ruralista.

- Não exerce seu poder de fiscalização ambiental a contento.

- O Novo Código Florestal foi um retrocesso.

- O Congresso não tem as políticas ambientais como prioridade.

\section{Temas e leis ambientais}

Entre os temas considerados mais relevantes na percepção dos cidadãos consultados, destacam-se: mudanças climáticas, combate ao desmatamento, educação ambiental e combate aos crimes ambientais (Tabela 5). O primeiro tema se justifica pelo fato de ter se tornado o principal em termos de visibilidade nos anos recentes (Barros, 2015b), após a divulgação de dados e estudos científicos pelo Painel Intergovernamental sobre Mudanças Climáticas, organização vinculada ao Programa das Nações Unidas para o Meio Ambiente (PNUMA), como o apoio da Organização Meteorológica Mundial (OMM). O poder de perspectivação de tais iniciativas contribuiu para elevar a politização do debate ambiental em escala global, com destaque para o nível de atenção pública voltada para os efeitos e consequências das mudanças no clima, o que contribuiu para intensificar sua relevância política (Ryan, 2017). 
O problema do desmatamento é considerado o calcanhar-de-aquiles do Brasil, no que se refere à ineficiência das políticas de contenção da exploração ilegal dos recursos florestais e das matas. Há um conjunto de fatores que se conjugam nesse processo e faz aumentar a cada ano o raio do chamado arco de desflorestamento, especialmente na Amazônia e no Cerrado (Domingues \& Bermann, 2012). Entre esses fatores destacam-se: (a) o avanço das fronteiras agrícolas; (b) o desflorestamento para o plantio de pasto; (c) queimadas; (d) extração ilegal de madeira; (e) atividade clandestina de mineração em áreas florestais. Apesar dos vários fatores mencionados, "as fazendas de médio e grande porte são responsáveis por cerca de $70 \%$ das atividades de desmatamento" (Fearnside, 2005, p. 113). Como assinala o autor, a retirada da vegetação facilita a propagação de incêndios, com impactos negativos como perda de biodiversidade e redução das chuvas, o que contribui para o aquecimento global. Como se trata de um público familiarizado com o debate sobre temas ambientais, certamente tais aspectos tiveram peso nas respostas dos informantes.

O destaque para a educação ambiental também está diretamente relacionado com o perfil do público das audiências, o qual compreende bem a função da educação na renovação de mentalidades e hábitos. Ressalta-se ainda o componente geracional, visto se tratar de um público com perfil predominantemente jovem, posto que 58,5\% dos informantes estão no intervalo etário de 18 a 40 anos (Tabela 1).

Gadotti (2008) atribui o aumento do interesse dos jovens pela sustentabilidade como uma contribuição da década da educação para o desenvolvimento sustentável (2005-2014), uma iniciativa da Organização das Unidas para promover a educação para a sustentabilidade. Para o autor, a educação é o primeiro contato dos jovens com a cultura da sustentabilidade, a fim de tomarem conhecimento das ideias e conceitos que os tornem capazes de conviver como cidadãos conscientes no contexto dos desafios da globalização capitalista. Em sua visão, "a formação de uma cidadania ambiental é um componente estratégico do processo de construção da democracia" (idem, p.31). Afinal, quando falamos em vida sustentável a entendemos como um modo de vida de bem-estar e bem viver para todos, em harmonia (equilíbrio dinâmico) com o meio ambiente: um modo de vida justo, produtivo e sustentável (idem, p.52). Para o autor isso implica educar para uma cultura da paz, da justiça social e da sustentabilidade.

O combate aos crimes ambientais apresenta correlação com educação ambiental em duas pers-

TABELA 5 - Quais os temas da agenda ambiental você considera mais relevantes.

\begin{tabular}{clcc}
\hline & \multicolumn{1}{c}{ TEMAS } & QUANT. & \% \\
\hline 1 & Mudanças climáticas & 310 & 22,45 \\
2 & Combate ao desmatamento & 258 & 18,68 \\
3 & Educação ambiental & 171 & 12,38 \\
4 & Combate aos crimes ambientais & 147 & 10,64 \\
5 & Proteção das matas e florestas & 117 & 8,47 \\
6 & Combate às queimadas & 79 & 5,72 \\
7 & Proteção animal & 76 & 5,50 \\
8 & Recursos hídricos & 71 & 5,14 \\
9 & Poluição urbana & 54 & 3,91 \\
10 & Desastres ambientais & 46 & 3,33 \\
11 & Agroecologia & 23 & 1,67 \\
12 & Resíduos sólidos & 22 & 1,59 \\
13 & Economia verde & 7 & 0,51 \\
\hline & TOTAL & $\mathbf{1 3 8 1}$ & $\mathbf{1 0 0 , 0 0}$ \\
\hline
\end{tabular}

FONTE: Elaboração própria. 
pectivas. A primeira é que a punição por atos e danos à natureza pode ser vista como educativa para o indivíduo e empresas infratores, especialmente pelas multas impostas pela legislação. A segunda está relacionada com falhas e lacunas na formação da consciência ecológica. Logo, se a educação ambiental não atingiu efetividade, as medidas legais de caráter punitivo devem ser acionadas, a fim de conter atos abusivos no plano individual e coletivo. Trata-se de uma perspectiva que encara o arsenal de dispositivos punitivos como estimuladores de reparação moral dos infratores.

A demanda punitiva relacionada ao meio natural emergiu na década de 1970, decorrente da concepção de que "o meio ambiente não é uma abstração, pois representa o espaço vital, a qualidade de vida e a própria saúde dos seres humanos, inclusive das gerações ainda por vir" (Hayek, 1976). Nesse diapasão, a Declaração de Estocolmo, em 1972, estabeleceu que o ser humano tem o direito fundamental a um ambiente de uma qualidade tal que lhe permita levar uma vida digna e gozar de bem-estar. Consagrou-se ainda a concepção de que crimes ambientais são atentados contra a própria espécie humana, posto que "a destruição deliberada do habitat ou do acesso a alimento ou água potável em escala significativa poderia representar uma infração aos direitos humanos fundamentais" (Freeland, 2005, p. 135).

Entre as leis ambientais aprovadas nas últimas décadas, os informantes destacam quatro delas: Lei do Sistema Nacional de Unidades de Conservação da Natureza; Lei da Política Nacional de Educação Ambiental; Lei dos Crimes Ambientais; Lei da Política Nacional do Meio Ambiente (Tabela 6). As unidades de conservação foram concebidas a partir da década de 1930 no Brasil, como resposta ao avanço da industrialização e urbanização. São ancoradas em uma perspectiva biocêntrica, que representa a natureza como um bem comum a ser conservado

TABELA 6 - Das leis ambientais aprovadas nas últimas décadas, quais você considera mais importantes?

\begin{tabular}{|c|c|c|c|}
\hline & LEIS & QUANT. & $\%$ \\
\hline 1 & Lei do Sistema Nacional de Unidades de Conservação da Natureza - 2000 & 338 & 25,30 \\
\hline 2 & Lei da Política Nacional de Educação Ambiental & 213 & 15,94 \\
\hline 4 & Lei da Política Nacional do Meio Ambiente - 1981 & 153 & 11,45 \\
\hline 5 & Lei do Saneamento Básico - 2007 & 102 & 7,63 \\
\hline 7 & Lei dos Resíduos Sólidos - 2010 & 80 & 5,99 \\
\hline 8 & Lei de Biossegurança - 2005 & 62 & 4,64 \\
\hline 9 & Novo Código Florestal - 2012 & 34 & 2,54 \\
\hline 10 & Lei de gestão das florestas públicas - 2006 & 30 & 2,25 \\
\hline
\end{tabular}

FONTE: Elaboração própria. 
na sua forma natural, a fim de manter as funções do ecossistema, além de assegurar a qualidade de vida humana (Pereira et al., 2017; Barros et al., 2018). O destaque a essa lei se deve certamente à percepção dos informantes quanto à importância das áreas protegidas, uma das bandeiras de grande parte das entidades e movimentos ambientalistas. Observa-se ainda a correlação da ênfase à conservação ambiental com os dois temas priorizados na Tabela 5: mudanças climáticas e combate ao desmatamento. Os ambientalistas são consensuais ao afirmar que o aumento de áreas protegidas contribui para reduzir os impactos do desflorestamento, uma das causas dos efeitos no clima global (Ryan, 2017).

A ênfase à Lei da Política Nacional de Educação Ambiental e Lei dos Crimes Ambientais na perspectiva dos informantes também apresenta correlação com os temas da Tabela 5, com base nos argumentos já mencionados de que a educação ambiental é considerada um importante fator de socialização para sustentabilidade (Carvalho, 2017). A punição por danos à natureza, contudo, é vista pelos inquiridos como um mecanismo que também não deve ser descartado.

A Lei da Política Nacional do Meio Ambiente consta entre os mais importantes do ranking certamente pelo marco histórico que ela representa. Editada ainda no período ditatorial (1981), a lei foi considerada inovadora, ao contemplar "um instrumental, em termos de políticas públicas para o meio ambiente" (Araújo, 2008, p. 236). Por outro lado, há estudos que mostram que a política ambiental brasileira se desenvolveu "de forma tardia em relação às demais políticas setoriais e em função das pressões externas dos países desenvolvidos e dos organismos multilaterais, como a ONU" (Barros, 2015a, p. 160). Pimentel et al. (2017, p. 129) salientam que é surpreendente o fato de a Lei não ter sido atualizada até hoje, visto que vários temais ambientais emergiram desde então. Sua principal contribuição, entretanto, na visão dos autores citados, foi inaugurar uma trilha de institucionalidade das políticas ambientais. Apesar das controvérsias existentes na literatura, o fato é que a referida lei foi mencionada pelos informantes como uma das mais importantes na área ambiental.

\section{Considerações finais}

$\mathrm{O}$ artigo cumpriu o objetivo de analisar as percepções de cidadãos que participaram das audiências públicas promovidas pela Comissão de Meio Ambiente e Desenvolvimento Sustentável (CMADS) da Câmara dos Deputados durante o ano de 2019. A análise mostra que a avaliação dos cidadãos é variável em relação a cada item examinado no estudo. Em relação às audiências em si, as percepções predominantes são "boa" (76,50\%) e "regular" (15,90\%).

Quanto ao teor dos debates, 61\% avaliam como bom. No caso da atuação dos deputados predomina a avaliação regular, com 63,20\%. A participação dos representantes de órgãos governamentais aparece com 52,50\% "boa" e 29,30\% “excelente". Quanto à atuação dos representantes do setor ambientalista, as percepções predominantes são de 48,60\% "boa" e 31,90\% "excelente". A avaliação em relação à atuação do Congresso Nacional em termos de políticas ambientais é muito negativa, com $95 \%$ de reprovação, somando-se as alternativas ruim e péssima.

Várias são as razões para essa avaliação negativa sobre a atuação do Congresso Nacio- 
nal, conforme foi demonstrado no texto, a partir da análise das respostas abertas. Destacam-se as críticas ao lobby da Bancada Ruralista em prol do setor do agronegócio e a aprovação de medidas que implicam retrocessos nas políticas de proteção aos ecossistemas nacionais. Esses dados corroboram os estudos que ressaltam que o Congresso Nacional tem apresentado uma trajetória de envolvimento tardio na área ambiental, tendendo para as políticas antiecológicas (Accioly \& Sánchez, 2012; Horochovski et al., 2020).

A participação nas audiências públicas é motivada por três fatores principais. Em primeiro lugar, destaca-se a atuação profissional na área ambiental, com 78,80\%. Em seguida está o vínculo com entidades ecológicas, ou seja, a militância ambiental, com $51,30 \%$. Em terceiro lugar está o vínculo com partidos de orientação ecológica, com 42,40\%.

Os dados confirmam a hipótese enunciada na introdução, ressaltando a inter-relação entre esses fatores. Isso explica ainda a existência de um público relativamente assíduo, que acompanha as audiências públicas da CMADS com uma frequência expressiva. Esse fator reforça a relevância de suas percepções, visto que se trata de um segmento que acompanha os debates tanto por meio das audiências públicas quanto de sua própria atividade profissional, militância e vínculo com os partidos que mais se dedicam a discutir temas da agenda ecológica em âmbito nacional.

\section{Referências}

Accioly, I.; Sánchez, C. Antiecologismo no Congresso Nacional: o meio ambiente representado na Câmara dos Deputados e no Senado Federal. Desenvolvimento e Meio Ambiente, (25)54, 397-108, 2012.

Allouche, A.; Nicolas, L. Entre perceptions, publicisation et stratégies d'acteurs, la difficile inscription des risques littoraux dans l'action publique: focus camarguais.Vertigo-la revue électronique en sciences de l'environnement, (2)21, 23-43, 2015.

Alonso, A.; Costa, V.; Maciel, D. Identidade e estratégia na formação do movimento ambientalista brasileiro. Novos estudos CEBRAP, 79, 151-167, 2007.

Anderson, T. L.; Leal, D. R. Free market versus political environmentalism. In: Zimmerman, M. E. Environmental Philosophy 2nd ed., Prentice Hall: New Jersey, [1993] 1998, 364-374.

Araújo, S. M. V. G. Vinte e cinco anos da Lei da Política Nacional do Meio Ambiente. Plenarium, (5)5, 236 - 243, 2008.

Barber, B. Strong democracy: participatory politics for a new age. San Francisco: Univ. of California Press, 1984.

Bardin, L. Análise de conteúdo. São Paulo: Edições 70, 2011.

Barros, A. T. de. O projeto de transparência do Senado Federal: entre a accountability e a propaganda política. Sociologias, Porto Alegre, 39(17), 338-368, 2013.

Barros, A. T. Política partidária e meio ambiente: a adesão dos partidos políticos brasileiros à agenda verde. Opinião Pública, 3(21), 693-733, 2015a.

Barros, A. T. Agenda Verde Internacional e seus Impactos no Brasil. Revista de Estudos e Pesquisas Sobre as Américas, 2(9),160-191, 2015b.

Barros, A. T. The Internet as environmental media: strategies of Brazilian political parties. Ambiente \& Sociedade, 1(20), 183-202, 2017a.

Barros, A. T. Brazil's Discourse on the Environment in the International Arena. Contexto Internacional, 2(39), 421-442, $2017 b$. 
Barros, A. T. Governança ambiental da metrópole: análise das propostas de governança ambiental para a cidade de São Paulo nas eleições de 2016. Polis, 3(52), 169-185, 2019.

Barros, A. T.; Monteiro, Adriana R.; Nóbrega Netto, Miguel G. Política, burocracia e mídia: lutas simbólicas em torno da divulgação das audiências públicas na Câmara dos Deputados. E-Legis, 29(12), 51-82, 2019.

Barros, A. T.; Resende, A. M.; Santos, T. T. Audiências públicas interativas na Câmara dos Deputados: além da função informacional. Revista Brasileira de Ciência Política, 26, 131-185, 2018.

Barry, J. Rethinking Green Politics: Nature, Virtue and Progress. London: Sage, 1999.

Barry, J. Green Political Theory. In: Geoghegan, V.; Wilford, R. (Eds.). Political Ideologies: An Introduction. London: Routlege, 2014, 153-178.

Bastos, C. R.; Martins, I. G. da S. Comentários à constituição do Brasil. São Paulo: Saraiva, v. 4, tomo I, 1995.

Benton, Ted. The greening of marxism. New York: Guilford Press, 1998.

Bernardes, C. B.; Barros, A. T. A cobertura jornalística das audiências públicas nas mídias legislativas. Estudos em Jornalismo e Mídia, 3(7), 260-272, 2010.

Biroli, F. Divisão sexual do trabalho e democracia. Dados, 3(59), 719-754, 2016.

Bomberg, E.; Burns, C. The environment committee of the european parliament: new powers, Old problems. London: Taylor \& Francis, 174-179, 2007.

Bourdieu, P. L'essence du néolibéralisme. Le Monde Diplomatique, 1998. Disponível em: <http://www.monde-diplomatique.fr/1998/03/BOURDIEU/3609>. Acesso em: jun. 2014.

Bourdieu, P. Espíritos de Estado: gênese e estrutura do campo burocrático. Razões práticas: sobre a teoria da ação. Campinas, São Paulo: Ed. Papirus, 2011.

Boy, D. Le Vert et le Rose: le poids de l'environnement et du social chez les militants Verts français. Paris: Galimard, 2002.
Brasil. Câmara dos Deputados. Comissão de Meio Ambiente e Desenvolvimento Sustentável. Relatório Anual de Produtividade Legislativa. Brasília, 2017.

Brasil. Câmara dos Deputados. Comissão de Meio Ambiente e Desenvolvimento Sustentável. Relatório Anual de Produtividade Legislativa. Brasília, 2019.

Burns, C.; Carter, N. The European parliament and climate change. The European Union as a leader in international climate change politics. London: Routledge, 2010.

Cabral, M. V. Grupos de simpatia partidária em Portugal: perfil sociográfico e atitudes sociais. Análise Social, 130(30), 175-205, 1995.

Canevari, T.; Banzato, G.; Cirio, G. Percepciones de vecinos sobre problemas sociales y ambientales en el Gran La Plata, Argentina: hacia una agenda de Gestión Integral del Territorio. Territorios, 3(40), 53-82, 2019.

Carvalho, I. C. M. Ecologia: um campo estratégico. Revista de Cultura Vozes, Petrópolis, 2(84), 234-241, 1990.

Carvalho, I. C. M. Educação ambiental: a formação do sujeito ecológico. Campinas: Cortez Editora, 2017.

Carvalho, I. C. M.; Steil, C. A. Percepção e ambiente: aportes para uma epistemologia ecológica. Revista Eletrônica Mestrado em Educação Ambiental, v. especial, 59-79, 2013.

Côrtes, C. P. G. da S. Para além do resultado das votações: Ressignificação do Propósito e da Eficácia de Audiências Públicas em Comissões Permanentes da Câmara dos Deputados, mediante Estudo de Caso. Brasília, Dissertação (Mestrado em Ciência Política) - CEFOR, 2020.

Dal Bosco, M. G. Audiência pública como direito de participação. Revista Jurídica Unigran, (3)1 7-23, 2002. Disponível em: <http://www.unigran.br/revistas/juridica/ ed_anteriores/08/artigos/10.pdf > . Acesso em: jun. 2015.

Doberty B.; De Geus M. Democracy and Green Political Thought: sustainability, Rights and Citizenship. London: Routledge, 1996.

Dobson A. 'Critical Theory and Green Politics'. In: Dobson A.; Lucardie, P. (Eds.). The Politics of Nature: explorations in green political theory. London: Routledge, 1993, 190-209. 
Dobson A. Democratising Green Theory: Preconditions and Principles. In: Doberty B., De Geus M. (Eds.). Democracy and Green Political Thought: sustainability, rights and citizenship. London: Routledge, 1996a, 132-150.

Dobson A. Representative Democracy and the Environment. In: Lafferty, W.; Meadowcroft, J. (Eds.). Democracy and the environment: problems and prospects. Cheltenham: Edward Elgar, 1996b, 125-148.

Domingues, M. S.; Bermann, C. O arco de desflorestamento na Amazônia: da pecuária à soja. Ambiente \& Sociedade, 2(15), 1-22, 2012.

Douglas, M. Cultural bias. London: Royal Anthropological Institute, 1978.

Douglas, M. Símbolos naturales. Madrid, España: Alianza Editorial, 1988.

Douglas, M. Introduction. In: Douglas, Mary (Org.) Essays on the Sociology of Perception. London: Routledge, 2013, $1-9$.

Dryzek, J. S. et al. Green states and social movements: environmentalism in the United States, United Kingdom, Germany, and Norway. Oxford: Oxford Press, 2003.

Dunlap, R. E. Lay perceptions of global risk: Public views of global warming in cross-national context. International Sociology, 4(13), 473-498, 1998.

Dunlap, R.; McCright, A.; Yarosh, H. J. The political divide on climate change: Partisan polarization widens in the U.S. Environment: Science and Policy for Sustainable Development, 5 (58), 4-23, 2016.

Durand, L. De las percepciones a las perspectivas ambientales: una reflexión teórica sobre la antropología y la temática ambiental. Nueva Antropología, 68(21), 75-87, 2008.

Duverger, T. Le Parti Socialiste et l'écologie - 1968-2011. Paris: Jean Jaurés Fondation, 2011.

Eckersley, R. Environmentalism and political theory: toward an ecocentric approach. New York: Suny Press, 1992.

Farhir Neto, L. Concepções filosóficas ambientalistas: uma análise das diferentes perspectivas. International Journal for Moral Philosophy, 3(5), 33-56, 2006.
Fearnside, P. M. Desmatamento na Amazônia brasileira: história, índices e conseqüências. Megadiversidade, (1)1, 113-123, 2005.

Fernández, Y. M. ¿ Por qué estudiar las percepciones ambientales? Una revisión de la literatura mexicana con énfasis en Áreas Naturales Protegidas. Espiral, 43(15),179202, 2008.

Filgueiras, F. A tolerância à corrupção no Brasil: uma antinomia entre normas morais e prática social. Opinião Pública, 2(15), 386-421, 2009.

Fiorino, D. J. Environmental risk and democratic process: a critical review. Columbia Journal Environmental, 82(14), 501-529, 1989.

Franchini, M. et al. The challenges of the anthropocene: from international environmental politics to global governance. Ambiente \& Sociedade, 3(20), 177-202, 2017.

Freeland, S. Direitos humanos, meio ambiente e conflitos: enfrentando os crimes ambientais. Revista Internacional de Direitos Humanos, 6(2), 119-127, 2005.

Gadotti, M. Educar para a sustentabilidade: uma contribuição à década da educação para o desenvolvimento sustentável. São Paulo: Instituto Paulo Feire, 2008.

Gibson, J. J. The ecological approach to visual perception. New York: Psychology Press, 1979.

Giddens, A. A constituição da sociedade. São Paulo: Martins Fontes, 2009.

Gudynas, E. Uma extraña pareja: los ambientalistas y el Estado em América Latina. Ecología Política, 7(3), 51-64, 1992

Guerra, A. M. V. A Participação Social e as Audiências Públicas. Brasília, Monografia (Especialização em Legislativo e Políticas Públicas) - CEFOR, 2010.

Guitián, E. G. História de la teoria política. Madri: Alianza, 1995.

Hardin, G. The Tragedy of the Commons. Journal of Natural Resources Policy Research, 3(1), 243-253, 2009.

Hayek, F. A.; Leube, K. R. Individualism and economic order. Chicago: University of Chicago Press, 1976. 
Hayward, T. Ecological thought: an introduction. Cambridge: Polity, 1995.

Holzer, W. A geografia humanista: uma revisão. Espaço e cultura: Rio de Janeiro, 1996.

Horochovski, R. R.; Junckes, I. J.; Serafim, T. R. quem interessam as políticas ambientais? redes de financiamento eleitoral empresarial na comissão de meio ambiente e desenvolvimento sustentável da Câmara dos Deputados. E-Legis, 31(13), 71-92, 2020.

Jacobbi, P.; Giatti, L. Nexos para a sustentabilidade: a busca por uma nova racionalidade. Ambiente \& Sociedade, 2(20), 12-24, 2017.

Jahn, D. Green politics and parties in Germany. The Political Quarterly, 3(68),174-182, 1997.

Jamison, A.; Cramer, J. The making of the new environmental consciousness: a comparative study of environmental movements in Sweden, Denmark and the Netherlands. Edinburgh: Edinburgh University Press, 1991.

Inglehart, R. Post-materialism in an environment of insecurity. American political science review 4(75), 880-900,1981.

Ingold, T. The perception of the environment: essays on livelihood, dwelling and skill. New York: Psychology Press, 2000.

Lee, T. Psicologia e meio ambiente. Rio de Janeiro: Zahar, 1977.

Lee, K. Social philosophy and ecological scarcity. London: Routledge, 1989.

Leff, H. Power-knowledge relations in the field of political ecology. Ambiente \& Sociedade, 3(20), 225-256, 2015.

Lima, P. G. da C.; Araújo, S. M. V. G.; Seraphim, A. P. A. C. C. O papel do Poder Legislativo. In: Steinberger, M. (Org.). Território, agentes-atores e políticas públicas espaciais. Brasília: Ler Editora, v. 1, 2017, 253-278.

Lobão, J. Crenças e percepções dos futuros investidores: um contributo para os Estudos Sociais em Finanças. Revista Crítica de Ciências Sociais, 118, 25-52, 2019.

Luke, T. Ecocritique: Contesting the Politics of Nature, Economy, and Culture. Minneapolis: University of Min- nesota Press, 1997.

Maldonado, M. A.; Sáiz, Á. V. Participación y representación en la teoría política verde: nuevos contenidos para viejos conceptos de la democracia liberal. Sistema: revista de ciencias sociales, 147(23), 79-103, 1998.

Marin, A. A. Pesquisa em educação ambiental e percepção ambiental. Pesquisa em educação ambiental, 1(3), 203222, 2008.

Medeiros, E.; Fonseca, Bruno. Conheça as 11 bancadas mais poderosas da Câmara. Congresso em Foco. Brasília,19 de fevereiro de 2016. Disponível em: https://congressoemfoco. uol.com.br/especial/noticias/conheca-as-11-bancadas-mais-poderosas-da-camara/ Acesso em 05/04/18.

Merleau-Ponty, M. Fenomenologia da percepção. São Paulo: Martins Fontes, 1999.

Mesquita, R.; Duarte, F. Dicionário de psicologia. Lisboa: Plátano, 1996.

Milton, K. Loving nature: towards an ecology of emotion. New York: Psychology Press, 2002.

Moreira Neto, D. Direito de participação política: legislativa, administrativa, judicial (fundamentos e técnicas constitucionais de legitimidade). Rio de Janeiro: Renovar, 1992.

Nóbrega, T. P. Corpo, percepção e conhecimento em Merleau-Ponty. Estudos de Psicologia, 24(13), 141-148, 2008.

Nunes, C. G. F.; Peres, J.; Silva, P. H. I. A pluralidade dos movimentos sociais. In: Steinberger, M. (Org.). Território, agentes-atores e politicas públicas espaciais. Brasília: Ler Editora, 2017, 337-368.

Paehlke, R. Environmentalism and the Future of Progressive Politics. Yale City: Yale University Press, 1989.

Pellenz, M.; Arizio, S. H. cidadania e justiça ecológica: perspectivas jurídicas numa sociedade liberal. Revista Húmus, 26(9), 326-339, 2019.

Pateman, C. Participation and democratic theory. Cambridge: Cambridge University Press, 1970.

Pepermans, Y.; Maeseele, P. The politicization of climate change: problem or solution? Wires Climate Change, 4(7), 478-485, 2016. 
Pepper, D. The Roots of Modern Environmentalism. London: Croom Helm, 1984.

Pereira, D. G. dos S. P. et al. Environmental protection areas: the case of the Bebedouro stream watershed. Ambiente \& Sociedade, 1(20), 105-126, 2017.

Pereira Rosa, Gonçalo. A Quercus nas notícias. Porto: Porto Editora, 2006.

Pimentel, L.; Novaes, V. W.; Dias, R. de C. Os agentes-atores na consolidação da política ambiental. In: Steinberger, M. (Org.). Território, agentes-atores e políticas públicas espaciais. Brasília: Ler Editora, 2017, 129-153.

Plumwood, Val. Has democracy failed ecology? An ecofeminist perspective. Environmental Politics, (4)4, 134-168, 1995.

Porrit, J. Seeing Green: The politics of ecology explained. Oxford, Blackwell, 1984.

Quadros, L. S.; Frei, F. Percepção ambiental dos residentes da cidade de Assis-SP com relação à arborização viária da Avenida Rui Barbosa. Revista da Sociedade Brasileira de Arborização Urbana, 2(4), 16-34, 2019.

Resende, C. A. da S. Representação de interesses na Câmara dos Deputados: estratégias, atores e agenda política. Revista Brasileira de Ciência Política, 23, 217-258, 2017.

Rodrigues, R. C. O ambientalismo liberal e as exigências conceituais de uma ética genuinamente ambiental. International Journal for Moral Philosophy, 3(5), 165-177, 2006.

Rohrschneider, R.; Miles, M. Representation through parties? Environmental attitudes and party stances in Europe in 2013. Environmental Politics, 4(24), 617-640, 2015.

Ryan, D. Politics and climate change: exploring the relationship between political parties and climate issues in Latin America. Ambiente \& Sociedade 3(20), 271-286, 2017.

Sachs, I. Estratégias de transição para o século XXI. Para pensar o desenvolvimento sustentável. São Paulo: Brasiliense, 1993.

Sainteny, G. Le Parti socialiste face à l'écologisme. De l'exclusion d'un enjeu aux tentatives de subordination d'un intrus. Revue Française de Science Politique 3(44), 424-461, 1994.
Sáiz, Á. V. Teoría política verde: balance de una disciplina emergente. Revista Española de Ciencia Política, 2(3), 181-194, 2000.

Sáiz Á. V. La izquierda verde: Aproximación a un modelo de izquierda radical en las sociedades democráticas. In: Anais do VII Congreso Español de Ciencia Política y de la Administración: Democracia y Buen Gobierno. Madrid, 21- 23 de sept., 2005.

Sáiz, V. A. Política y Medio Ambiente. Cidade do México: Editorial Porrúa, 2014.

Sandler, B. Grow or die: Marxist theories of capitalism and the environment. Rethinking Marxism, 2(7), 38-57, 1994.

Santos, A. V. A institucionalização do movimento ambientalista: um estudo da formação do Partido Verde no Brasil. São Paulo, Dissertação (Mestrado em Ciências Sociais) - PUCSP, 2008.

Scagliola, A. Crisis de los partidos y crisis ambiental. Montevideo: Centro Latino Americano de Ecología Social, 2002.

Serafim, L. Controle Social nas Agências Reguladoras brasileiras. Revista Eletrônica de Ciências Sociais, 2(5), 202-221, 2008.

Silva, R. H.; Barbosa, A. M. E. S. A audiência pública do TST sobre terceirização: um espaço social de lutas político-cognitivas. Politica \& Sociedade, 30(14), 72-101, 2015.

Spretnak, C.; Capra, F. Green Politics: The Global Promise. San Francisco: Bear and Co., 1985.

Troiano, M. Atores empresariais, instituições e leis: uma proposta de estudo das audiências públicas nas comissões permanentes. In: Anais do $39^{\circ}$. Encontro Anual da Anpocs. Caxambu, 26 a 30 de out. de 2015.

Tuan, Yi-Fu. Topophilia: a study of environmental perceptions, attitudes, and values. Columbia: Columbia University Press, 1972.

Vieira, B. M. O movimento ambientalista frente às reconfigurações políticas e sociais no Brasil (1985-2002). Estudos de Sociologia, 40(21), 117-135, 2016.

Wong, J. K. A Dilemma of Green Democracy. Political Studies 1(64), 136-155. 2016. 
Yearley, S. The Green Case: A Sociology of Environmental Issues, Arguments and Politics. London: Routledge, 2014.

Zampieri, E. Ação dos grupos de pressão no processo decisório das comissões permanentes do Congresso Nacional. E-Legis, 13(12), 122-136, 2013.
Zorzal, G.; Carlos, E. Audiências públicas do legislativo estadual: fatores endógenos e exógenos na análise da efetividade da participação. Revista de Sociologia e Política, (25)64, 23-46, 2017. 